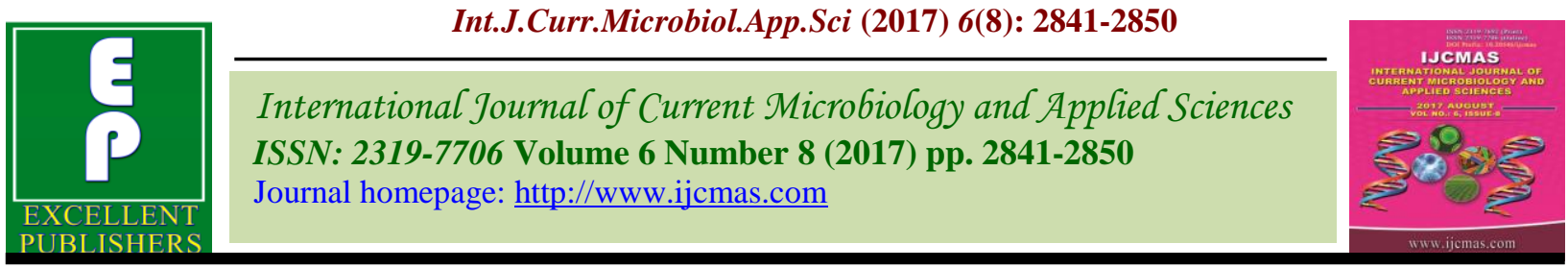

Original Research Article

https://doi.org/10.20546/ijcmas.2017.608.339

\title{
Incidence of Mycoflora and Mycotoxigenic Fungi in Poultry Feeds in Warangal (T.S.), India
}

\author{
A. Rajender Reddy, D. Parvathi and V. Krishna Reddy* \\ Department of Botany, Kakatiya University, Warangal-506009 (T.S.), India \\ *Corresponding author
}

\section{A B S T R A C T}

\section{Keywords}

Poultry feeds,

Molds,

Mycotoxins,

Layers, Broilers.

Article Info

Accepted:

23 June 2017

Available Online:

10 August 2017
Extensive investigations carried out on the incidence of common and toxigenic fungi revealed that all types of broiler feeds were found to be infested by common as well as toxigenic fungi and none of the samples was free from contamination. Aspergillus species were dominant in all the samples, followed by species of Penicillium, Fusarium, Alternaria and Chaetomium. Highest number of fungal genera (11) were recorded in broiler concentrate feed amended and broiler concentrate feed with coarse of maize flour. Layer feeds showed association of different fungal species. Absidia, Aspergillus, Brevilegnia, Curvularia, Fusarium, Penicillium and Mucor were the major fungal genera isolated from layer feed samples of this region. Toxigenic studies on fungal isolates of poultry feeds revealed that aflatoxin, sterigmatocystin, ochratoxin A, penicillic acid, cyclopiazonic acid, fumonisin B1, HT-2 toxin, moniliformin, deoxynivalenol, nivalenol, T-2 toxin, zearalenone, diacetoxyscirpenol, citrinin, patulin, islanditoxin, roridin E, penicillic acid were the common mycotoxins produced by them. But the percentage of toxigenic isolates varied with the sample. In all the feed samples, highest number of Aspergillus flavus isolates were found to be toxigenic followed by A. ochraceus for ochratoxin, Penicillium citrinum for citrinin. In sunflower meal more number of Aspergillus parasiticus strains were positive for aflatoxin. It is concluded that high incidence of toxigenic Aspergillus flavus and A. ochraceus strains for aflatoxin and ochratoxin A indicates the probability of presence of these toxins in the feed samples.

\section{Introduction}

Poultry is one of the fastest growing segments of the agricultural sector in India today. About 3 million farmers directly and 15 million agrarian farmers indirectly are employed in the poultry industry which contributes to the tune of Rs.26,000 crore to the national income. Both Telangana and Andhra Pradesh account for production of 3.5 crore live birds every month, which constitutes one-third of the country's production, apart from six crore eggs per a day. In revenue terms, poultry's contribution to the state's annual GDP is estimated to be about Rs.20,000 crore with employment to close to 20 lakh people. Poultry industry mainly located around Hyderabad city, Vishakapatnam, Chittoor and Warangal districts. According to a survey conducted by our laboratory, in Warangal district annually 26 lakh layer birds are grown and average egg production is 20,00,000 per day and the number of broiler birds grown and consumed in this district are 15,00,000 per month. More than six commercial poultry feed brands are being used in this district especially for broiler. Feed is the key input for successful 
poultry production and it accounts for the major cost of poultry production constituting up to 70 percent of the total cost. Poultry diets are formulated from a mixture of ingredients that include cereal grains, cereal by-products, fats, plant protein sources, animal byproducts, vitamin mineral supplements, crystalline amino acids and feed additives.

Two types of feeds i.e. broiler feed and layers feed are formulated. Since poultry feeds are rich in all types of nutrients easily to prone to microbial growth at appropriate conditions. Defects in formulations, faulty storage conditions and unseasonal rains promote the infestation of feeds by microorganisms. Fungal contamination of poultry feeds is a regular occurrence on a worldwide scale and detrimental to the poultry industry. Against this background, investigations were taken up for one year duration (June, 2014 to May, 2015) to assess the qualitative and quantitative incidence of mycoflora of different types of poultry feeds. An attempt was made to assess the incidence of mycotoxigenic fungi

\section{Materials and Methods}

\section{Studies on mycoflora}

Isolation and enumeration of mycotoxigenic fungi associated with poultry feed, feed ingredients

\section{Study region}

Samples of commercial poultry feeds, feed ingredients were collected for one year at monthly intervals from poultry farms located in Warangal district, Telangana state of India and the respective feed manufacturers located in other places also. In case of farm mixed poultry feeds, individual feed ingredients along with mixed feeds were also collected.

\section{Sampling criteria}

Samples of commercially prepared poultry feeds, farm mixed poultry feeds and feed ingredients were collected through systematic random sampling. For each sample, three initial samples of three $\mathrm{kg}$ each were collected from different places. After thorough mixing a composite sample of $1 \mathrm{Kg}$ placed in a sterile polythene bag was brought to the laboratory for inoculation on the culture media. Conditions of the sample at the collection time were recorded.

\section{Isolation and assessment of fungi}

\section{Dilution plate technique (Waksman, 1922)}

$10 \mathrm{~g}$ of each sample was taken in $250 \mathrm{ml}$ conical flask containing $100 \mathrm{ml}$ of $0.1 \%$ sterilized peptone water and subjected to horizontal shaking for 30 minutes and dilutions were made as desired. $0.5 \mathrm{ml}$ of this suspension was poured aseptically into sterilized Petriplates containing cooled Asthana and Hawker's medium A $\left(\mathrm{KNO}_{3}\right.$ $3.5 \mathrm{~g}, \mathrm{KH}_{2} \mathrm{PO}_{4} 1.75 \mathrm{~g}, \mathrm{MgSO}_{4} .7 \mathrm{H}_{2} \mathrm{O} 0.75 \mathrm{~g}$, glucose $5 \mathrm{~g}$, Agar-agar $16 \mathrm{~g}$ and distilled water $1000 \mathrm{ml})$.The medium was poured by making gentle rotational movement so as to ensure uniform spreading of the sample.

Petri plates thus prepared were incubated in an inverted position at $27 \pm 2^{\circ} \mathrm{C}$ under dark condition. To suppress the bacterial growth and to restrict the fungal colonies streptomycin and rose Bengal were added. The fungal colonies developing from the plates were isolated and later on purified by repeated sub culturing. Slides were made on lactophenol cotton blue from individual colonies and the fungi were identified based on morphological features. The percentage of incidence, frequency and abundance of individual fungus were calculated with the help of following formulae. 


\section{Number of colonies of a species in all plates \\ $\%$ of incidence $=$ \\ Total number of colonies of all the \\ species in all plates \\ Number of observations in \\ which a species appeared \\ $\%$ of frequency = ---------------------- $\times 100$ \\ Total number of observations}

Total number of colonies of a species in all observations

$\%$ of abundance = ----------------------- $\times 100$

Total number of colonies in all observations

\section{Identification of fungi}

Identification of fungi was made on the basis of their colony characters on different culturing media (macroscopic) and microscopic characters (Klich and Pitt, 1988; Singh et al., 1991; Barnett and Hunter, 1998).

Different macroscopic characters used to identify included colony form, size, elevation, margin/border, surface, color (pigmentation), opacity, texture and margins (rim) of colony.

\section{Screening of fungi for mycotoxin elaboration}

Different mycotoxins produced by species of Aspergillus, Fusarium and Penicillium were detected by standard methods. Aflatoxins (Stack and Pohland, 1975); ochrotoxin-A (Gimeno, 1979); sterigmatocystine (Adey and Mateles, 1964); penicillic acid and citrinin (Gorst-Allman and Steyn, 1979); diacetoxy scirpenol, deoxynivalenol and nivalenol (Ramakrishna and Bhat, 1987); moniliformin fumonisin B1, zearalenone, HT-2 toxin and T-2 toxin (Kamimura et al., 1981); Cyclopiazonic acid (Rathinavelu and Shanmugasundaram, 1983); patulin (Subramanian, 1982) and islanditoxin (Takeda et al., 1973).

\section{Results and Discussion}

\section{Broiler feeds}

The mycoflora isolated from broiler concentrate feeds are shown in the Table 1. It is evident from the table that a variety of fungi was associated with the broiler concentrate feed samples of Warangal district. 27 fungal species representing 11 genera were recovered from feed samples. Of these, most of the species belonged to Aspergillus, Fusarium and Penicillium. Genus Aspergillus represented with 8 species, similarly Fusarium with 6 speceis and Penicillium with 3 species. Highest total number of 20 fungal species was isolated in June 2014 and January 2015, whereas least number of fungal species appeared in the month of April 2015. A total of 8 species of Aspergillus appeared in the month of July 2014, similarly 6 species of Fusarium appeared in the month of October, 2014 and 3 speceis of Penicillium appeared in 3 months September, 2014, December 2014 and Febraury 2015. None of the Fusarium species appeared in April 2015, and similarly no Penicillium species were recovered in May 2015. Aspergillus humicola, A. candidus, A. flavus and Cladosporium cladosporioides showed highest percentage of frequency appeared for 10 months of the study out of 12 months. Chaetomium cupreum recorded with lowest percentage of frequency appeared only in 2 months of the study. Rests of the fungal species studied are recorded with intermediate frequency. A. flavus stands for highest incidence for 9 months, while $F$. moniliforme showed highest incidence in October 2014 to January 2015. Highest abundance was recorded with $A$. flavus, whereas lowest abundance was recorded with Absida repens.

Toxigenic potential of different species of mycoflora isolated from broiler concentrate feed were screened and the results are 
presented in the Table 2. A critical perusal of the table reveals that many fungi colonizing broiler concentrate feeds are toxigenic. However, the degree of toxigenicity varied with the fungus. Out of 126 isolates of Aspergillus flavus, 87 isolates elaborated aflatoxin and sterigmatocystin, only 4 isolates of A. nidulans were positive for sterigmatocystin, out of 25 isolates screened. Out of 58 isolates of $A$. ochraceus 22, 11 and 2 isolates were positive for ochratoxin A, penicillic acid and cyclopiazonic acid respectively. Only 2 isolates of $A$. versicolar were able to produce cyclopiazonic acid out of 18 isolates screened.

Out of 26 isolates of Fusarium avenaceum 8, $3,4,2$ and 5 isolates respectively were found to be positive for fumonisin $\mathrm{B}_{1}$, HT-2 toxin, moniliformin, $\mathrm{T}-2$ toxin and zearalenone production. On the other hand, screening of 32 isoltes of $F$. equiseti revealed that $6,8,9$ and 11 isolates were positive for production of moniliformin, nivalenol, T-2 toxin and zearalenone, respectively. Out of 43 isolates of $F$. moniliforme 11, 13, 3, 6, 8 and 1 isolates were found to produce diacetoxyscirpenol, fumonisin $\mathrm{B}_{1}$, moniliformin, nivalenol, $\mathrm{T}-2$ toxin and zearalenone respectively. Out of 14 isolates of $F$. oxysporum screened 3, 3, and 4 isolates were positive for production of moniliformin, nivalenol and zearalenone respectively. Only one isolate of $F$. solani proved to be positive for T-2 toxin out of 14 isolates screened.

Nineteen isolates of Penicillium citrinum elaborated citrinin when 56 isolates were screened for toxin production. Nine isolates of $P$. griseofulvum elaborated patulin when 27 isolates were screened for their toxigenic potentials. Only 3 isolates of $P$. islandicum elaborated island toxin when 14 isolates were screened. It was observed that $A$. versicolar failed to produce sterigmatocystin. Similarly $F$. avenaceum, $F$. equiseti, $F$. moniliforme have failed to produce nivalenol, diacetoxyscirpenol, HT-2 toxin respectively in culture filtrates.

\section{Layer feeds}

\section{Layer chick feed}

Mycoflora isolated form layer chick feed is presented in the Table 3 . An overall 12 fungal species representing 8 genera were isolated during 12 months of the study. Highest number of fungal species appeared in October 2014, whereas least number of fungal species appeared for 4 months i.e. June to August 2014 and in April 2015 during entire study. Most of the fungal species belonged to Aspergillus and Alternaria represented by 4 and 3 species respectively. All the Aspergillus spp. appeared in the month of May 2015 whereas all the Alternaria spp. appeared in September 2014. Aspergillus flavipes showed highest incidence for 5 months during entire study. In the month of November 2009, Alternaria humicola, Aspergillus flavus, A. ochraceus, Curvularia geniculata and Mucor globosus have showed highest incidence. Curvularia geniculata was recorded with highest incidence in June 2009. A. ochraceus showed highest frequency appeared in nine months of the study. Alternaria solani with least frequency traced for 2 months in the study. Alternaria flavipes showed highest abundance with highest number of colonies.

Toxigenic potential of different fungi isolated from layer chick feed were screened and the results obtained are presented in Table 4. From the table it is clear that fungi colonizing layer chick feed were having toxin producing potentials. Eight isolates of A. clavatus elaborated patulin out of 12 strains were isolated. Similarly, 6 and 1 isolate of A. flavus were positive for aflatoxin and sterigmatocystin when 25 isolates were screened for their toxigenic capabilities. 
Table.1 Month-wise qualitative and quantitative analysis of incidence of mycoflora of broiler concentrate feed (June, 2014 to May, 2015)

\begin{tabular}{|c|c|c|c|c|c|c|c|c|c|c|c|c|c|c|}
\hline \multirow{2}{*}{ Name of the fungus } & \multicolumn{12}{|c|}{ Percentage of incidence } & \multirow{2}{*}{$\begin{array}{l}\text { Percentage of } \\
\text { frequency }\end{array}$} & \multirow{2}{*}{$\begin{array}{l}\text { Percentage } \\
\text { of abundance }\end{array}$} \\
\hline & $\mathrm{A}$ & B & $\mathrm{C}$ & $\mathrm{D}$ & $\mathrm{E}$ & $\mathrm{F}$ & $\mathrm{G}$ & $\mathrm{H}$ & I & $\mathrm{J}$ & $\mathrm{K}$ & $\mathrm{L}$ & & \\
\hline Absidia glauca & 1.14 & 0.65 & - & - & 1.10 & 0.62 & - & 3.94 & - & - & 5.50 & - & 50.00 & 1.07 \\
\hline A. repens & - & - & 1.56 & 0.54 & - & - & 1.08 & 0.49 & - & 1.60 & - & - & 41.66 & 0.43 \\
\hline Alternaria fasciculata & 3.41 & 1.96 & 1.56 & - & - & - & 2.16 & 2.46 & - & 2.40 & - & 2.70 & 66.66 & 1.34 \\
\hline Aspergillus humicola & 2.27 & 1.31 & - & 3.23 & 1.66 & 1.24 & 0.54 & 3.94 & 2.21 & - & 2.75 & 1.35 & 83.33 & 1.83 \\
\hline A. candidus & 1.14 & 7.19 & 2.34 & 0.54 & 7.73 & 4.97 & - & 1.97 & 7.18 & - & 5.50 & 6.76 & 83.33 & 3.60 \\
\hline A. flavus & 18.18 & 18.30 & 31.25 & 32.26 & - & - & 15.14 & 18.72 & 19.89 & 33.60 & 29.36 & 40.54 & 83.33 & 19.66 \\
\hline A. glaucus & 6.25 & 5.23 & - & - & - & 2.48 & - & - & - & 4.80 & 4.59 & 4.05 & 50.00 & 1.99 \\
\hline A. nidulans & 1.14 & 1.96 & - & - & - & 3.73 & 2.16 & 5.42 & 1.10 & 8.80 & - & - & 58.33 & 2.09 \\
\hline A. ochraceus & 12.50 & 11.76 & 8.59 & - & - & 1.24 & - & 0.99 & - & 12.00 & 22.94 & 25.68 & 66.66 & 6.12 \\
\hline A. orantus & - & 3.92 & 2.34 & - & 2.21 & 5.59 & 5.95 & 5.91 & 6.08 & - & - & 2.70 & 66.66 & 3.11 \\
\hline A. versicolor & 2.27 & 8.50 & - & - & 11.60 & 7.45 & 5.95 & 2.96 & 4.42 & 11.20 & 10.09 & - & 75.00 & 5.37 \\
\hline Chaetomium cupreum & - & - & - & - & 1.66 & - & - & 0.99 & - & - & - & - & 16.66 & 0.27 \\
\hline C. globosum & - & - & - & 2.15 & - & - & 1.08 & - & - & - & 5.50 & - & 25.00 & 0.64 \\
\hline Cladosporium cladosporioides & 4.55 & 3.92 & 9.38 & 5.91 & 8.29 & 8.70 & 5.41 & 0.99 & - & 2.40 & - & 1.35 & 83.33 & 4.40 \\
\hline Curvularia geniculata & - & 5.23 & - & - & 2.21 & 1.86 & - & 0.99 & - & 0.80 & - & 1.35 & 50.00 & 1.02 \\
\hline C. lunata & 3.41 & - & 7.03 & - & 6.08 & 2.48 & 3.24 & 1.48 & 0.55 & 1.60 & - & - & 66.66 & 2.26 \\
\hline Eurotium chevalieri & 1.14 & - & - & 1.08 & 0.55 & 1.86 & - & - & 1.10 & - & 0.92 & 1.35 & 58.33 & 0.64 \\
\hline Fusarium avenaceum & 4.55 & 3.92 & 3.91 & - & 2.21 & - & 4.86 & 7.39 & 6.08 & 3.20 & - & 1.35 & 75.00 & 3.38 \\
\hline F. equiseti & 1.14 & 1.96 & 1.56 & - & 4.42 & 6.21 & 3.24 & - & - & 1.60 & - & - & 58.33 & 1.77 \\
\hline F. moniliforme & 15.91 & - & - & 11.83 & 14.36 & 16.15 & 15.68 & 18.72 & 11.05 & 11.20 & - & - & 66.66 & 10.90 \\
\hline F. oxysporum & - & 11.76 & 8.59 & 8.06 & 8.84 & - & 14.05 & 7.88 & 9.94 & - & - & - & 58.33 & 6.44 \\
\hline F. poae & 6.82 & - & - & 5.91 & 9.94 & 12.42 & - & 7.39 & 6.08 & - & - & - & 50.00 & 4.67 \\
\hline F. solani & 7.39 & 7.19 & 7.81 & 6.45 & 7.73 & 6.83 & - & - & 5.52 & - & - & 10.81 & 66.66 & 4.78 \\
\hline Penicillium citrinum & 4.55 & 4.58 & 11.72 & 5.91 & - & - & 8.65 & - & 11.05 & - & 11.01 & - & 58.33 & 4.78 \\
\hline P. griseofulvum & - & - & - & 6.45 & 6.08 & 9.94 & 8.11 & 6.40 & 6.63 & - & - & - & 50.00 & 4.24 \\
\hline P. islandicum & 1.14 & - & - & 9.68 & 3.31 & 4.97 & 2.16 & - & 1.10 & 4.80 & - & - & 58.33 & 2.47 \\
\hline Rhizopus stolonifer & 1.14 & 0.65 & 2.34 & - & - & 1.24 & 0.54 & 0.99 & - & - & 1.83 & - & 58.33 & 0.70 \\
\hline
\end{tabular}

A=June, 2014; B= July, 2014; C=August, 2014; D = September, 2014; E = October, 2014; F = November, 2014; G = December, 2014; H = January, 2015; I = February, 2015; J=March, 2015, K=April, 2015; L=May, 2015. 
Table.2 Screening of toxigenic fungi and respective toxins produced in broiler concentrate feed

\begin{tabular}{|c|c|c|c|c|}
\hline Name of the fungus & Number of strains screened & Number of toxin producing strains & $\%$ of positive strains & Toxin produced \\
\hline \multirow[t]{2}{*}{ Aspergillus flavus } & 126 & 87 & 69.1 & Aflatoxin \\
\hline & & 17 & 13.5 & Sterigmatocystin \\
\hline A. nidulans & 25 & 4 & 16.0 & Sterigmatocystin \\
\hline \multirow[t]{2}{*}{ A. ochraceus } & 58 & 22 & 37.9 & Ochratoxin-A \\
\hline & 58 & 11 & 19.0 & Penicillic acid \\
\hline \multirow[t]{2}{*}{ A. versicolor } & 18 & 2 & 11.1 & Cyclopiazonic acid \\
\hline & & ND & -- & Sterigmatocystin \\
\hline \multirow[t]{6}{*}{ Fusarium avenaceum } & 26 & 8 & 30.8 & Fumonisin B1 \\
\hline & & 3 & 11.5 & HT-2 toxin \\
\hline & & 4 & 15.4 & Moniliformin \\
\hline & & ND & -- & Nivalenol \\
\hline & & 2 & 7.7 & $\mathrm{~T}-2$ toxin \\
\hline & & 5 & 19.2 & Zearalenone \\
\hline \multirow[t]{5}{*}{ F. equiseti } & 32 & ND & -- & Diacetoxyscirpenol \\
\hline & & 6 & 18.8 & Moniliformin \\
\hline & & 8 & 25.0 & Nivalenol \\
\hline & & 9 & 28.1 & $\mathrm{~T}-2$ toxin \\
\hline & & 11 & 34.4 & Zearalenone \\
\hline \multirow[t]{7}{*}{ F. moniliforme } & 43 & 11 & 25.6 & Diacetoxyscirpenol \\
\hline & & 13 & 30.2 & Fumonisin B1 \\
\hline & & ND & -- & HT-2 toxin \\
\hline & & 3 & 7.0 & Moniliformin \\
\hline & & 6 & 14.0 & Nivalenol \\
\hline & & 8 & 18.6 & $\mathrm{~T}-2$ toxin \\
\hline & & 1 & 2.3 & Zearalenone \\
\hline \multirow{3}{*}{ F. oxysporum } & 14 & 3 & 21.4 & Moniliformin \\
\hline & & 3 & 21.4 & Nivalenol \\
\hline & & 4 & 28.6 & Zearalenone \\
\hline$F$. solani & 14 & 1 & 7.1 & $\mathrm{~T}-2$ toxin \\
\hline Penicillium citrinum & 56 & 19 & 33.9 & Citrinin \\
\hline P. griseofulvum & 27 & 9 & 33.3 & Patulin \\
\hline P. islandicum & 14 & 3 & 21.4 & Islanditoxin \\
\hline
\end{tabular}

$\mathrm{ND}=$ Not detected 
Table.3 Month-wise qualitative and quantitative analysis of incidence of mycoflora of layer chick feed (June, 2014 to May, 2015)

\begin{tabular}{|c|c|c|c|c|c|c|c|c|c|c|c|c|c|c|}
\hline \multirow[b]{2}{*}{ Name of the fungus } & \multicolumn{12}{|c|}{ Percentage of incidence } & \multirow[b]{2}{*}{$\begin{array}{l}\text { Percentage } \\
\text { of frequency }\end{array}$} & \multirow{2}{*}{$\begin{array}{c}\text { Percentage } \\
\text { of } \\
\text { abundance }\end{array}$} \\
\hline & A & B & $\mathrm{C}$ & $\mathrm{D}$ & $\mathrm{E}$ & $\mathrm{F}$ & G & $\mathrm{H}$ & $\mathrm{I}$ & $\mathrm{J}$ & $\mathrm{K}$ & $\mathrm{L}$ & & \\
\hline Alternaria flavipes & - & 22.22 & 53.33 & 37.50 & 34.78 & - & - & 32.00 & 22.22 & 41.66 & - & - & 58.33 & 25.00 \\
\hline A. humicola & - & - & - & 10.41 & - & 13.04 & 15.38 & - & - & - & 11.11 & - & 33.33 & 4.66 \\
\hline A. solani & - & - & - & 4.16 & - & - & - & - & - & - & - & 14.28 & 16.66 & 1.69 \\
\hline Aspergillus clavatus & 15.38 & 33.33 & - & - & 6.52 & 8.69 & - & - & 11.11 & - & - & 7.14 & 50.00 & 5.08 \\
\hline A. flavus & - & - & - & 4.16 & 10.86 & 13.04 & - & 16.00 & - & - & 55.55 & 42.85 & 50.00 & 10.59 \\
\hline A. giganteus & - & - & 6.66 & - & 4.34 & - & 7.69 & 12.00 & 22.22 & 8.33 & - & 14.28 & 58.33 & 5.08 \\
\hline A. ochraceus & 7.69 & 33.33 & 33.33 & - & - & 13.04 & 15.38 & 32.00 & - & 8.33 & 22.22 & 7.14 & 75.00 & 11.01 \\
\hline Curvularia geniculata & 61.53 & - & - & 12.50 & 4.34 & 13.04 & 15.38 & 4.00 & - & - & - & - & 50.00 & 9.32 \\
\hline Drechslera sp. & - & - & - & 4.16 & 2.17 & - & - & 4.00 & - & 25.00 & - & 14.28 & 41.66 & 3.81 \\
\hline Epicoccum nigrum & - & - & 6.66 & - & 4.34 & 4.34 & - & - & 11.11 & - & - & - & 33.33 & 2.11 \\
\hline Fusarium solani & - & - & - & 16.66 & 21.73 & 8.69 & 7.69 & - & 33.33 & - & - & - & 41.66 & 10.16 \\
\hline Mucor globosus & 15.38 & 11.11 & - & 6.25 & 8.69 & 13.04 & 38.46 & - & - & 16.66 & 11.11 & - & 66.66 & 8.89 \\
\hline White sterile mycelium & - & - & - & 4.16 & 2.17 & 13.04 & - & - & - & - & - & - & 25.00 & 2.54 \\
\hline
\end{tabular}

A=June, 2014; B= July, 2014; C=August, 2014; D = September, 2014; E = October, 2014; F = November, 2014; G = December, 2014; H = January, 2015; I = February, 2015; J=March, 2015; K=April, 2015; L=May, 2015.

Table.4 Screening of toxigenic fungi and respective toxins produced in layer chick feed

\begin{tabular}{lcccl}
\hline Name of the fungus & $\begin{array}{c}\text { Number of } \\
\text { strains screened }\end{array}$ & $\begin{array}{c}\text { Number of } \\
\text { toxin producing strains }\end{array}$ & $\begin{array}{c}\text { \% of positive } \\
\text { strains }\end{array}$ & Toxin produced \\
\hline Aspergillus clavatus & 12 & 8 & 33.3 & Patulin \\
A. flavus & 25 & 6 & 24.0 & Aflatoxin \\
A. ochraceus & 13 & 1 & 4.0 & Sterigmatocystin \\
& & 2 & 15.4 & Ochratoxin-A \\
\end{tabular}

$\mathrm{ND}=$ Not detected 
Table.5 Month-wise qualitative and quantitative analysis of incidence of mycoflora of layer grower feed (June, 2014 to May, 2015)

\begin{tabular}{|c|c|c|c|c|c|c|c|c|c|c|c|c|c|c|}
\hline \multirow{2}{*}{ Name of the fungus } & \multicolumn{12}{|c|}{ Percentage of incidence } & \multirow{2}{*}{$\begin{array}{c}\text { Percentage of } \\
\text { frequency }\end{array}$} & \multirow{2}{*}{$\begin{array}{c}\text { Percentage of } \\
\text { abundance }\end{array}$} \\
\hline & $\mathrm{A}$ & $\mathrm{B}$ & $\mathrm{C}$ & $\mathrm{D}$ & $E$ & $\mathrm{~F}$ & $\mathrm{G}$ & $\mathrm{H}$ & I & $\mathbf{J}$ & $\mathrm{K}$ & $\mathrm{L}$ & & \\
\hline Alternaria alternata & 16.67 & - & - & 5.88 & - & - & - & 16.67 & 7.69 & - & - & - & 33.33 & 3.48 \\
\hline A. fasciculata & - & 16.67 & 14.29 & 11.76 & - & 7.69 & - & - & 7.69 & - & 8.33 & - & 50.00 & 5.22 \\
\hline Aspergillus flavus & 16.67 & - & - & 5.88 & 15.79 & - & 17.65 & 33.33 & 15.38 & 27.78 & - & 7.69 & 66.66 & 12.21 \\
\hline A. ochraceous & 16.67 & 16.67 & 7.14 & - & 10.53 & - & - & 8.33 & 15.38 & 16.67 & 16.67 & 15.38 & 75.00 & 9.88 \\
\hline A. oryzae & - & - & 14.29 & 5.88 & - & 23.08 & 11.76 & - & - & 5.56 & - & - & 41.66 & 5.22 \\
\hline A. parasiticus & 8.33 & 8.33 & 14.29 & - & - & - & 5.88 & - & 7.69 & - & 8.33 & - & 50.00 & 4.07 \\
\hline A. repens & - & - & - & - & 5.26 & - & 17.65 & - & - & 11.11 & - & - & 25.00 & 3.48 \\
\hline A. ustus & - & 16.67 & 7.14 & 5.88 & 15.79 & 30.77 & - & - & 7.69 & - & 16.67 & 7.69 & 66.66 & 8.72 \\
\hline A. versicolor & 8.33 & - & 7.14 & - & 5.26 & - & - & - & 7.69 & - & - & - & 33.33 & 2.33 \\
\hline Curvularia affinis & 16.67 & 16.67 & 14.29 & 5.88 & - & 15.38 & - & - & 7.69 & 11.11 & 16.67 & 15.38 & 75.00 & 9.30 \\
\hline C. lunata & - & - & 7.14 & - & - & - & 5.88 & - & - & 5.56 & - & - & 25.00 & 1.74 \\
\hline C. subulata & - & - & - & 5.88 & - & - & 5.88 & 8.33 & - & - & - & 7.69 & 33.33 & 2.33 \\
\hline Epicoccum nigrum & - & 8.33 & - & 5.88 & 5.26 & - & - & - & 7.69 & 11.11 & 8.33 & - & 50.00 & 4.07 \\
\hline Melanospora damnosa & - & - & - & - & - & - & 5.88 & - & - & 5.56 & - & - & 16.66 & 1.16 \\
\hline Memnoniella echinata & - & - & 7.14 & - & - & - & 5.88 & 16.67 & - & 5.56 & - & 15.38 & 41.66 & 4.07 \\
\hline Penicillium citrinum & 16.67 & 8.33 & - & 17.65 & 26.32 & 23.08 & 11.76 & 8.33 & - & - & 16.67 & 15.38 & 75.00 & 12.21 \\
\hline P. digitatum & - & - & 7.14 & 11.76 & 5.26 & - & - & - & 15.38 & - & 8.33 & 7.69 & 50.00 & 4.65 \\
\hline P. griseofulvum & - & 8.33 & - & 17.65 & 10.53 & - & 11.76 & 8.33 & - & - & - & 7.69 & 50.00 & 5.81 \\
\hline
\end{tabular}

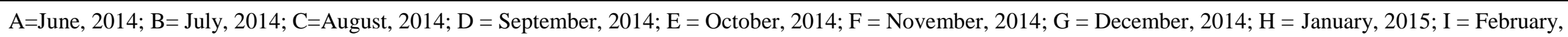
2015; J=March, 2015; K=April, 2015; L=May, 2015.

Table.6 Screening of toxigenic fungi and respective toxins produced in layer grower feed

\begin{tabular}{|c|c|c|c|c|}
\hline Name of the fungus & Number of strains screened & Number of toxin producing strains & $\%$ of positive strains & Toxin produced \\
\hline \multirow[t]{2}{*}{ Aspergillus flavus } & 18 & 6 & 33.3 & Aflatoxin \\
\hline & & 2 & 11.1 & Sterigmatocystin \\
\hline \multirow[t]{2}{*}{ A. ochraceus } & 15 & 3 & 20.0 & Ochratoxin-A \\
\hline & & 6 & 40.0 & Penicillic acid \\
\hline A. parasiticus & 7 & 4 & 57.1 & Aflatoxin \\
\hline \multirow[t]{2}{*}{ A. versicolor } & 3 & 2 & 66.7 & Cyclopiazonic acid \\
\hline & & ND & -- & Sterigmatocystin \\
\hline Penicillium citrinum & 11 & 4 & 36.4 & Citrinin \\
\hline P. griseofulvum & 6 & ND & -- & Patulin \\
\hline
\end{tabular}


On the other hand, only 2 isolates of $A$. ochraceus reported to produce ochratoxin A out of 13 isolates screened. However, $A$. ochraceus did not produce penicillic acid.

\section{Layer grower feed}

The mycoflora isolated from layer grower feed was shown in the Table 5. It is evident from the table that a variety of fungal species are associated with the grower feed samples of Warangal district. Eighteen fungal species representing 7 genera were recorded from feed samples. Of these, most of the species belonged to Aspergillus, Curvularia and Penicillium. Genus Aspergillus represented by 7 species similarly Curvularia with 3 species and Penicillium with 3 species. Highest total number of fungal species appeared in September 2014 whereas least number of fungal species appeared in the month of June 2014 and January 2015. A total of 7 speceis of Aspergillus did not appear in any month during 12 months of the study. Total 3 species of Penicillium appeared in the months of September, October 2014 and May 2015 and total 3 species of Curvularia were not traced out in any one month of the study. Aspergillus ochraceus, Curvularia affinis and Penicillium citrinum showed highest frequency appeared for 9 months of the study out of 12 months. Melanospora damnosa recorded with lowest percentage of frequency appeared only in 2 months of the study. Rest of the fungal species was recorded with moderate frequency. Aspergillus flavus stands for highest incidence for 3 months. While Penicillium citrinum showed highest incidence in September 2014 and October 2014. Highest abundance was found with $A$. flavus and $P$. citrinum, whereas lowest abundance with Melanospora damnosa.

Different fungi isolated from layer grower feed were screened for their toxigenic potentials and the results are presented in the
Table 6. A critical study of the table reveals that many fungi colonizing layer grower feed were able to produce different mycotoxins. However, the degree of toxigenicity varied with the fungus. Out of 18 isolates of $A$. flavus 6 and 2 isolates respectively were positive for aflatoxin and sterigmatocystin production. Three and 6 isolates of $A$. ochraceus elaborated ochratoxin A and penicillic acid out of 15 isolates screened for their toxigenic potentials. Similarly 4 isolates of $A$. parasiticus elaborated aflatoxin out of 7 isolates screened, on the other hand, out of 3 isolates of $A$. versicolor 2 isolates were positive for production of cyclopiazonic acid. However sterigmatocystin was not produced by $A$. versicolor. Out of 11 isolates of Penicillium citrinum only 4 isolates produced citrinin. However, A. versicolor failed to produce sterigmatocystin, similarly patulin by $P$. griseofulvum.

\section{Acknowledgements}

The authors are thankful to the Head, Department of Botany for providing facilities and the financial assistance of UGC is gratefully acknowledged.

\section{References}

Adye, J., and Mateles, R.C. 1964. Incorporation of labeled compounds into aflatoxins. Biochimica et Biophysica Acta 86, 418-420.

Barnett, H., and Hunter, B. 1998. Descriptions and illustrations of genera. Illustrated genera of imperfect fungi $\left(4^{\text {th }}\right.$ ed.). American Phytopathological Society, St. Paul, MN. pp. 68-69.

Gimeno, A., 1979. Thin layer chromato graphic determination of aflatoxins, ochratoxins, sterigmatocystin, zearalenone, citrinin, T-2 toxin, diacetoxyscirpenol, penicillic acid, patulin and penitrem A. Journal-Association of Official 
Analytical Chemists 62, 579-585.

Gorst-Allman, C.P., and Steyn, P.S. 1979.

Screening methods for the detection of thirteen common mycotoxins. Journal of Chromatography A 175, 325-331.

Kamimura, H., Nishijima, M., Yasuda, K., Saito, K., Ibe, A., Nagayama, T., Oshiyama, H. and Naoi, Y. 1981. Stimultaneous detection of fusarial toxins. Journal-Association of Official Analytical Chemists 64, 1067.

Klich, M.A., and Pitt, J.I. 1988. A laboratory guide to the common Aspergillus species and their teleomorphs. Commonwealth Scientific and Industrial Research Organization, Division of Food Processing, New South Wales, Australia. p. 116.

Ramakrishna, Y., and Bhat, V. 1987. Comparision of different spray reagents for identification of trichothecenes. Current Science 56, 524-526.

Rathinavelu, A. and Shanmugasundaram, E.R. (1983): Simple colorimetric estimation of cyclopiazonic acid in contaminated food and feeds. JournalAssociation of Official Analytical Chemists 67, 38-40.
Singh, K., Frisvad, J.C., Thrane, U. and Mathur, S. 1991. An illustrated manual on identification of some seed-borne. Aspergilli, Fusaria, Penicillia. pp.3169.

Stack, M.E., and Pohland, A.E. 1975. Collaborative study of a method for chemical confirmation of the identity of aflatoxins. Journal of the Association of Official Analytical Chemists 58, 110113.

Subramanian, T., 1982. Colorimetric determination of patulin production by Penicillium patulin. Journal of the Association of Official Analytical Chemists 65, 5-7.

Takeda, N., Seo, S., Ogihara, Y., Sankawa, U., Iitaka, I., Kitagawa, I. and Shibata, S. 1973. Studies on fungal metabolites-XXXI: Anthraquinonoid colouring matters of Penicillium islandicum sopp and some other fungi (-) luteoskyrin, (-) rubroskyrin, (+) rugulosin and their related compounds. Tetrahedron 29, 3703-3719.

Waksman, S.A., 1922. A method for counting the number of fungi in the soil. Journal of Bacteriology 7, 339.

\section{How to cite this article:}

Rajender Reddy A., D. Parvathi and Krishna Reddy, V. 2017. Incidence of Mycoflora and Mycotoxigenic Fungi in Poultry Feeds in Warangal (T.S.). Int.J.Curr.Microbiol.App.Sci. 6(8): 2841-2850. doi: https://doi.org/10.20546/ijcmas.2017.608.339 